\title{
Applying methane and carbon flow balances for determination of first-order landfill gas model parameters
}

\author{
Jin-Kyu Park ${ }^{1}$, Yong-Gil Chong ${ }^{2}$, Kazuo Tameda ${ }^{3}$, Nam-Hoon Lee $^{2+}$ \\ ${ }^{1}$ Ecowillplus Co., Ltd., Anyang 14001, Republic of Korea \\ ${ }^{2}$ Department of Environmental and Energy Engineering, Anyang University, Anyang 14029, Republic of Korea \\ ${ }^{3}$ Graduate School of Engineering, Fukuoka University, Fukuoka 814-0180, Japan
}

\begin{abstract}
Landfill gas (LFG) emissions from a given amount of landfill waste depend on the carbon flows in the waste. The objective of this study was to more accurately estimate the first-order decay parameters through methane $\left(\mathrm{CH}_{4}\right)$ and carbon flow balances based on the analysis of a full-scale landfill with long-term data and detailed field records on LFG and leachate. The carbon storage factor for the case-study landfill was 0.055 g-degradable organic carbon (DOC) stored per g-wet waste and the amounts of $\mathrm{DOC}$ lost with the leachate were less than $1.3 \%$. The appropriate $\mathrm{CH}_{4}$ generation rate constant $(\mathrm{k})$ for bulk waste was $0.24 \mathrm{y}-1$. The the $\mathrm{CH}_{4}$ generation potential ( $\mathrm{L} 0$ ) values ranged $33.7-46.7 \mathrm{~m} 3-\mathrm{CH}_{4} \mathrm{Mg}-1$, based on the fraction of DOC that can decompose (DOCf) value of 0.40 . Results show that $\mathrm{CH} 4$ and carbon flow balance methods can be used to estimate model parameters appropriately and to predict long-term carbon emissions from landfills.
\end{abstract}

Keywords: Carbon emissions, First-order decay model, Landfill gas, Leachate, Methane and carbon flow balances

\section{Introduction}

Landfill gas (LFG), including methane $\left(\mathrm{CH}_{4}\right)$ emissions from landfills, needs to be accurately quantified and predicted to establish appropriate $\mathrm{CH}_{4}$ management strategies because landfills are known to be anthropogenic sources of $\mathrm{CH}_{4}$. Most of the models used to predict $\mathrm{LFG}$ and $\mathrm{CH}_{4}$ generated from landfills are based on the first-order decay (FOD) model:

$$
G=W L_{o} k e^{-k t}
$$

where $G$ is the $\mathrm{CH}_{4}$ generation rate in volume per time, $W$ is the mass of waste in place, $L_{0}$ is the $\mathrm{CH}_{4}$ generation potential in volume per mass, $k$ is the $\mathrm{CH}_{4}$ generation rate constant in reciprocal time, and $t$ is the time elapsed after disposal of the waste.

The FOD model is based on waste disposal rates and the application of two parameters: $L_{0}$ and $k$. For $L_{0}$, the Intergovernmental Panel on Climate Change (IPCC) provides the following equation [1]:

$$
L_{o}=D O C \times D O C_{f} \times M C F \times F \times \frac{16}{12}
$$

where $D O C$ is the amount of degradable organic carbon in waste, $\mathrm{kg} \mathrm{Mg}^{-1}, D O C_{f}$ is the fraction of $D O C$ that can decompose, $M C F$ is the $\mathrm{CH}_{4}$ correction factor for aerobic decomposition, $F$ is the volume fraction of $\mathrm{CH}_{4}$ in the $\mathrm{LFG}$, and 16 and 12 are the molar masses of $\mathrm{CH}_{4}$ and carbon, respectively.

The $k$ value generally describes the rate constant associated with waste decomposition, moisture, and other environmental conditions [2]. In addition, the $\mathrm{CH}_{4}$ recovery efficiency $(R)$ and oxidation factor (OX) should be considered to estimate $\mathrm{CH}_{4}$ surface emission. $\mathrm{R}$ is affected by landfill operating conditions and LFG collection methods [3]. $\mathrm{OX}$ is the fraction of $\mathrm{CH}_{4}$ biologically oxidized by the cover soil.

The FOD model parameters are highly dependent on environmental conditions. Site-specific the FOD model parameters improve the model results. In most cases, $L_{0}$ and $k$ are estimated using laboratory tests (e.g., biochemical methane potential (BMP) and lysimeter experiments), or using model fitting with LFG short-term or extraction data. However, the $L_{0}$ and $k$ values obtained via laboratory tests are typically greater than those obtained from full-scale data, because the waste samples are digested under optimum conditions. Thus, FOD models typically overestimate the amounts
This is an Open Access article distributed under the terms of the Creative Commons Attribution Non-Commercial License (http://creativecommons.org/licenses/by-nc/3.0/) which permits unrestricted non-commercial use, distribution, and reproduction in any medium, provided the original work is properly cited.

Copyright (C) 2020 Korean Society of Environmental Engineers
Received February 25, 2019 Accepted May 22, 2019

${ }^{\dagger}$ Corresponding author

Email: nhlee@anyang.ac.kr

Tel: +82-31-467-0891 Fax: +82-31-467-0789

ORCID: 0000-0001-8999-5603 
of LFG produced at landfills because of the use of regulatory default model parameters that are intended to produce conservative emissions estimates [4]. Cho et al. [5] suggested that the $L_{0}$ obtained from laboratory test needs to be adjusted using a correction factor, but the parameter still has significant uncertainty. Thus, the parameters in the FOD model should be estimated under site-specific landfill conditions, including those related to waste characteristics, moisture content, and temperature [4].

For these reasons, more data from full-scale landfills are needed with complete data sets that provide descriptions of LFG quality and quantity, waste placement rates, and gas collection efficiency. Historically, however, FOD modeling was based on a limited number of field observations or an incomplete description of the landfill and LFG collection system [2]. Full-scale landfills with sufficient data that can be used for determination of FOD model parameters are rare.

The model fitting method that uses LFG short-term or extraction data is limited when employing default model parameters. For example, when a $k$ value is estimated using the LFG extraction data, the errors in the estimated $L_{0}$ based on assumptions for $D O C$ and $D O C_{f}$ can significantly affect the estimates of $k$ [6]. Thus, $D O C$ and $D O C_{f}$ are fixed within a plausible range, and $\mathrm{k}$ should be optimized by model fitting method of the collected LFG data.

Additionally, a suitable validation of the FOD model parameters requires comparison with all of the site emission measurement data for long periods of time. Continued field measurement will reduce the uncertainty and inaccuracy in future estimates of $\mathrm{CH}_{4}$ emission [7].

The objective of this study was to more accurately estimate the primary parameters $\left(D O C_{f}, R, \mathrm{OX}, L_{0}\right.$ and $\left.k\right)$ through $\mathrm{CH}_{4}$ and carbon flow balances based on analysis of a full-scale landfill with long-term data and detailed field records on waste composition, LFG, and leachate. This study was also conducted to estimate the DOC of disposed waste using BMP values for each waste component in a case-study landfill. Estimating behavior of carbon release in landfill can assists in the determining of $D O C$. The extent of carbon conversion is defined as the fraction of the organic carbon converted to $\mathrm{CH}_{4}$ and $\mathrm{CO}_{2}$, which is equivalent to the $D O C_{f}$. This study is unique and valuable because actual long-term measured LFG data (10 y) from a Korean landfill was used to determine the primary parameters for the FOD modeling. In addition, a comparison was made between the measured and the model results. Further, carbon emissions derived from both the modeled and measured data were compared to validate the estimated parameters. This study could help to reduce the uncertainty involved in using FOD model parameters and predicted LFG emissions, and to enhance understanding of the long-term behavior of carbon via LFG and leachate in landfills.

\section{Methodology}

\subsection{Methane and Carbon Flow Balances}

For mass balance analysis, the landfill is considered as a system. Landfill $\mathrm{CH}_{4}$ mass balance can be presented using Eq. (3) [8]. However, $\mathrm{CH}_{4}$ storage $(\triangle S)$ was considered to be negligible in this study, because in comparison to the other components for long periods of time, changes in landfill $\mathrm{CH}_{4}$ storage are generally assumed to be insignificant [7]. The $O X$ and $R$ values for a case-study landfill were estimated through a landfill $\mathrm{CH}_{4}$ mass balance approach:

$$
Q_{g}=Q_{o x}+Q_{e m}+Q_{c}+\triangle S
$$

where $Q_{g}$ is the generated $\mathrm{CH}_{4}, \mathrm{~m}^{3} \mathrm{y}^{-1} ; \mathrm{O}_{o x}$ is the oxidized $\mathrm{CH}_{4}$, $\mathrm{m}^{3} \mathrm{y}^{-1} ; Q_{e m}$ is the emitted $\mathrm{CH}_{4}, \mathrm{~m}^{3} \mathrm{y}^{-1} ; Q_{c}$ is the collected $\mathrm{CH}_{4}$, $\mathrm{m}^{3} \mathrm{y}^{-1}$; and $\triangle S$ is the change in $\mathrm{CH}_{4}$ storage, $\mathrm{m}^{3} \mathrm{y}^{-1}$.

LFG emissions from a given amount of landfill waste depend on the carbon flows in the waste. Estimating carbon release via LFG and leachate assists in the understanding of the long-term behavior of carbon release in landfill [9]. In order to determine $D O C_{f}$, the amount of carbon released from organic waste decomposition needs to be estimated. The quantity of carbon generated in LFG and leachate could be estimated using Eq. (4) and (5) [10]:

$$
\begin{gathered}
C_{g, t}=\frac{V_{L F G, t} \times 12}{22.4 \times 1,000} \\
C_{l e, t}=\left(C O D_{\text {con }, t} \times P_{t} \times 10^{-6}\right) \times \frac{3}{8}
\end{gathered}
$$

where $C_{g, t}$ is the amount of carbon generated via LFG at t year, $\mathrm{Mg} \mathrm{y}^{-1} ; V_{L F G, t}$ is the volume fraction of LFG at $\mathrm{t}$ year, $\mathrm{m}^{3} \mathrm{y}^{-1} ; 12$ is the molar mass of carbon, $\mathrm{kg} \mathrm{mol}^{-1} ; 22.4$ is the molar volume, $\mathrm{m}^{3} \mathrm{~mol}^{-1} ; C O D_{\text {con,t }}$ is the chemical oxygen demand (COD) concentration of leachate at $\mathrm{t}$ year, $\mathrm{mg} \mathrm{L}^{-1} ; P_{t}$ is the flow rate of leachate at $\mathrm{t}$ year, $\mathrm{m}^{3} \mathrm{y}^{-1} ; C_{l, t}$ is the amount of carbon emitted via leachate at $\mathrm{t}$ year, $\mathrm{Mg}^{-1}$; $t$ is the time since the initial waste placement, $\mathrm{y}$; and $3 / 8$ is the conversion from COD to C.

The total quantity of carbon $\left(C_{s}\right)$ generated via $\mathrm{LFG}$ and leachate can be calculated from the following equations.

$$
\begin{gathered}
C_{s}=C_{g+} C_{l e} \\
C_{g}=C_{i n}+C_{c} \\
C_{i n}=C_{o x}+C_{e m}
\end{gathered}
$$

where $C_{\text {in }}$ is the amount of carbon in LFG flux under the landfill cover soil, $\mathrm{Mg} \mathrm{y}^{-1} ; C_{c}$ is the amount of carbon collected through the LFG collection system, $\mathrm{Mg}^{-1} ; C_{o x}$ is the amount of carbon oxidized through the cover soil, $\mathrm{Mg}^{-1}$; and $C_{e m}$ is the amount of carbon emitted via LFG, Mg $\mathrm{y}^{-1}$.

\subsection{Case-Study Landfill}

Full-scale landfills with sufficient data that can be used for modeling purposes are rare. Thus, a case-study landfill needs to have significant data on waste composition, waste amount, leachate, and LFG data for long periods of time. In this study, the selected case-study landfill is the Sudokwon landfill site 1 (SLS 1) located in Inchon City, Korea. The Sudokwon landfill is the largest landfill in Korea. SLS 1 began operation in 1992 and was closed in 2000, to be replaced by site 2 which has been operational since 2000 . 
Horizontal LFG collection wells were initially installed in 1997 and the LFC collection system was changed to accommodate vertical LFG collection wells in 2003. Collected LFG was initially flared and was then used to supply a power plant (50 MW). The LFG flare systems were later closed in 2008. The final cover for SLS 1, which was installed in 2004, consists of a gas venting layer (30 $\mathrm{cm})$, an overlying barrier clay layer $(45 \mathrm{~cm})$, an overlying gravel drainage layer $(30 \mathrm{~cm})$, and an overlying vegetation cover $(60 \mathrm{~cm})$. The waste composition data for SLS 1 are provided in Table S1 [11].

From 2005 to 2014, $\mathrm{CH}_{4}$ and $\mathrm{CO}_{2}$ emission measurements were conducted at SLS 1 using the dynamic flux chamber method as well as leachate generation rate and COD concentration [11, 12]. The measured data are shown in Table 2. IPCC [1] reported that the quantity of $D O C$ emitted from landfill leachate should be considered an estimation of $D O C_{f}$ because in countries with high precipitation rates, the amount of $D O C$ lost through leaching can be higher than in countries with drier climates. Thus, the quantity of DOC emitted from SLS 1 was calculated using Eq. (5) based on the leachate generation rate and the COD concentration (Table S2).

\subsection{Estimation of FOD Modeling Parameters}

\subsubsection{DOC}

DOC is the organic carbon in wastes that is accessible to biochemical decomposition, which includes the biochemical processes in a cell or organism. From the processes, the organic carbon is decomposed in anaerobic processes to $\mathrm{CH}_{4}$ and $\mathrm{CO}_{2}$; this implies that the biological method is only appropriate for estimating DOC. In this study, a BMP test was suggested as the biological method because the BMP value is the ultimate amount of $\mathrm{CH}_{4}$ produced under optimal anaerobic conditions. DOC can be calculated using the following equation:

$$
D O C=\frac{L_{o}}{D O C_{F} \times F \times M C F \times \frac{16}{12}}
$$

Eq. (9) was based on an assumed DOC value of 1.0 because the BMP value generally represents an upper limit on the $\mathrm{CH}_{4}$ potential of waste. $L_{0}$ values for the annually disposed wastes were calculated using the BMP values for each waste component weighted according to the waste composition for SLS 1. Table S3 shows the BMP data for each waste component, which were obtained in previous Sudokwon landfill site research [13]. Most waste in landfills generates a gas with about $50 \% \mathrm{CH}_{4}$. Only material that includes substantial amounts of fat or oil can generate gas of more than $50 \% \mathrm{CH}_{4}$. Therefore, the $\mathrm{F}$ value of $50 \%$ was used for the calculation in Eq. (9). MCF is defined as the portion of carbons that decompose anaerobically. The default value of MCF for anaerobic landfills is set as 1.0, which means that $100 \%$ of organic carbon is decomposed anaerobically. The MCF value of 1.0 was used in this study, because the BMP test was conducted under anaerobic conditions. The DOC value of the waste $\left(D O C_{M S W}\right)$ can be calculated from the weighted average of the DOC of each biodegradable component $\left(D O C_{i}\right)$, as described in Eq. (10):

$$
D O C_{M S W}=\sum_{i=1}^{n} D O C_{i} \times(w t . \text { fraction })_{i}
$$

where $i$ is the $i$ th waste component.

\subsubsection{OX}

To calculate the efficiency of $\mathrm{CH}_{4}$ oxidation, a method derived by Christophersen et al. [14] was used. This method is derived from the fact that the ratio of $\mathrm{CO}_{2}$ and $\mathrm{CH}_{4}$ shifts with the oxidation process while the total volume of $\mathrm{CO}_{2}$ and $\mathrm{CH}_{4}$ remains constant. Using this method, it is assumed that $\mathrm{CO}_{2}$ is not dissolved in the infiltrating water, and the production of gas in the soil is negligible, which means that under stationary conditions, the total LFG flux at the surface of the cover soil is equal to that at the bottom of the cover soil. The total LFG flux can be calculated from the following equation:

$$
\text { Total } \begin{aligned}
L F G \text { flux } & =\mathrm{CH}_{4} \text { emission flux }\left(Q_{\text {em }}\right)+\mathrm{CO}_{2} \text { emission flux } \\
& =\mathrm{CH}_{4} \text { influx }+\mathrm{CO}_{2} \text { influx }
\end{aligned}
$$

where $\mathrm{CH}_{4}$ influx and $\mathrm{CO}_{2}$ influx are the $\mathrm{CH}_{4}$ and $\mathrm{CO}_{2}$ fluxes under the landfill cover soil, $\mathrm{m}^{3} \mathrm{y}^{-1}$.

Knowing the total LFG flux at the surface of the cover soil and the $\mathrm{CH}_{4} / \mathrm{CO}_{2}$ ratio at the bottom of the cover soil, the $\mathrm{CH}_{4}$ influx can be calculated from the following equation [14]:

$$
C H_{4 \text { influx }}=\left(Q_{\text {em }}+C O_{2 \text { emission flux }}\right) \times \frac{Q_{c}}{Q_{c}+C O_{2 \text { collected flux }}}
$$

where $\mathrm{CO}_{2}$ collected flux is the collected $\mathrm{CO}_{2}$ flux, $\mathrm{m}^{3} \mathrm{y}^{-1}$.

The difference between the $\mathrm{CH}_{4}$ emission flux $\left(Q_{e m}\right)$ and $\mathrm{CH}_{4}$ influx is the amount of methane. Thus, $O X$ was estimated using Eq. (13):

$$
O X(\%)=\frac{C H_{4 \text { influx }}-Q_{\text {em }}}{C H_{4 \text { influx }}} \times 100
$$

\subsection{3. $\mathrm{R}$}

$\mathrm{CH}_{4}$ recovery is directly quantified using mass flow measurements. The collection efficiency (R) for a measurement period is defined as the fraction of generated gas collected from an entire landfill. The $R$ value can be calculated using Eq. (14):

$$
R(\%)=\frac{Q_{c}}{Q_{g}} \times 100
$$

\subsection{4. $\mathrm{k}$}

The $k$ value was calculated from the measured carbon emissions using non-linear regression. Since waste decomposition does not begin immediately after disposal, $\mathrm{CH}_{4}$ production begins either in one or two year after the waste is disposed of in a landfill [15]. In this study, it was assumed that $\mathrm{CH}_{4}$ generation was initiated one year after disposal. SLS 1 closed in 2000, which meant that $\mathrm{CH}_{4}$ generation could have increased up to 2001, and then consistently decreased. Thus, the amount of carbon emissions at year $\mathrm{t}$ after 2001 can be described by a first-order kinetic model: 


$$
C_{t, 2001}=C_{2001} e^{-k t}
$$

where $C_{t, 2001}$ is the amount of carbon emissions at year t since 2001, $\mathrm{Mg} \mathrm{y}^{-1} ; C_{2001}$ is the maximum carbon emission at year 0 in 2001, $\mathrm{Mg} \mathrm{y}^{-1}$; and $k$ is the $\mathrm{CH}_{4}$ generation rate constant, $\mathrm{y}^{-1}$.

\subsection{5. $\mathrm{DOC}_{\mathrm{f}}$}

The total amount of carbon emission was calculated from the sum of the carbon emitted from disposed wastes for long periods of time as the degradable waste decomposes during that period of time. In this study, the LandGEM model [16] was used to estimate the $D O C_{f}$ value using the estimated $k$ value via Eq. (15), as presented in Eq. (16):

$$
Q_{g}=\sum_{i=1}^{n} \sum_{j=0.1}^{1} k L_{0}\left[\frac{M_{i}}{10}\right] e^{-k t_{i, j}}
$$

where, $i$ is the time period of waste disposal $\left(\mathrm{y}^{-1}\right), j$ is $1 / 10$ th time increments $\left(\mathrm{y}^{-1}\right), n$ is the duration of waste acceptance at the landfill (y), $k$ is the FOD rate constant $\left(\mathrm{y}^{-1}\right), M_{i}$ is the tonnage of waste disposed in year $i(\mathrm{Mg}), L_{0 i}$ is the $\mathrm{CH}_{4}$ generation potential of waste disposed in year $i\left(\mathrm{~m}^{3} \mathrm{Mg}^{-1}\right)$, and $t_{i, j}$ is the age of $j$ th section of waste $M_{i}(\mathrm{y})$.

It was assumed that the $D O C$ present in the landfill was potentially converted. However, some of the carbon was not converted because conditions in the landfill do not allow biodegradation. This is accounted for by a dissimilation factor, $D O C_{f}$. Eq. (17) can be used to calculate $D O C_{f}$. The cumulative carbon emission is given by the sum of the carbon emitted via LFG and leachate in different years:

$$
\operatorname{DOC}_{f}(\%)=\frac{\text { Cumulative carbon emission }}{\text { Total DOC }} \times 100
$$

In this study, a first-order carbon emission model was applied to validate the estimated $D O C_{f}$ and $k$ values. The model was developed on the basis of a single-stage generation trend, assuming a peak carbon emission rate at the direct commencement of the carbon emissions. The carbon emission rate decreases thereafter according to a first-order kinetic, as expressed in Eq. (18) and (19):

$$
\begin{aligned}
& D D O C_{m, t}=W_{t} \times D O C_{t} \times D O C_{f} \\
& C_{t}=D D O C_{m, t} \times\left(e^{-k(t-1)}-e^{-k t}\right)
\end{aligned}
$$

where, $D D O C_{m, t}$ is the mass of decomposable DOC at time $t, \mathrm{Mg}$ $\mathrm{y}^{-1} ; W_{t}$ is the mass of waste deposited at time $\mathrm{t}, \mathrm{Mg}^{-1} ; t$ is the time since the initial waste placement, y; and $C_{t}$ is the carbon emission rate at time $t, \mathrm{Mg} \mathrm{\textrm {y } ^ { - 1 }}$.

\section{Results and Discussion}

\subsection{Estimation of DOC Using BMP Value}

Table 1 shows the DOC values calculated using Eq. (9) based on an assumed $D O C_{f}$ value of 1.0 from this study when the $\mathrm{CH}_{4}$ density is $0.716 \mathrm{~g} \mathrm{~L}^{-1}$ at $0^{\circ} \mathrm{C}$. For the annually disposed wastes, considering waste components other than plastic wastes, the $D O C$ values ranged from 79.1 to $109.1 \mathrm{~kg} \mathrm{Mg}^{-1}$. Plastics are composed of fossil carbons and thus were not considered in the evaluation of the $D O C$ values. The minimum $D O C$ was $79.1 \mathrm{~kg} \mathrm{Mg}^{-1}$ in 2000 , because the non-combustible waste component (39.72\%) was the largest portion of disposed waste in SLS 1, as reported in Table S1. The calculated $D O C$ values were slightly higher than the ranges reported in the literature. Mou et al. [17] showed that DOC for combustible waste ranges from 79.6 to $87.4 \mathrm{~kg} \mathrm{Mg}^{-1}$. Cho et al. [5] reported that the BMP value for fresh waste is $53.1 \mathrm{~kg} \mathrm{Mg}^{-1}\left(74 \mathrm{~m}^{3} \mathrm{Mg}^{-1}\right)$, which means that based on an assumption of a $D O C_{f}$ of 1.0 , the $D O C$ is $79.7 \mathrm{~kg} \mathrm{Mg}^{-1}$. The higher $D O C$ values obtained in this study can be explained by the higher proportion of food and paper wastes.

\subsection{Estimation of $\mathrm{R}$ and $\mathrm{OX}$ Using the $\mathrm{CH}_{4}$ Flow Balance}

In this study, total $\mathrm{CH}_{4}$ generation flux $\left(\mathrm{Q}_{\mathrm{g}}\right)$ can be calculated using Eq. (3). The measured data of collected $\mathrm{CH}_{4}$ flux $\left(\mathrm{Q}_{\mathrm{c}}\right)$ and $\mathrm{CH}_{4}$

\begin{tabular}{|c|c|c|c|c|}
\hline Year & Amount of disposed waste (Mg) & $\begin{array}{c}L_{0}\left(\mathrm{~kg} \mathrm{CH} \mathrm{CH}_{4} \mathrm{Mg}^{-1}\right) \\
\left({ }^{*} D O C_{f}=1\right)\end{array}$ & $D O C\left(\mathrm{~kg} \mathrm{Mg}^{-1}\right)$ & Total $D O C(\mathrm{Mg})$ \\
\hline 1992 & $1,462,254$ & $67.2 \pm 10.3$ & $100.8 \pm 15.4$ & $147,438 \pm 22,488$ \\
\hline 1993 & $8,088,911$ & $72.7 \pm 10.8$ & $109.1 \pm 16.3$ & $882,299 \pm 131,532$ \\
\hline 1994 & $11,664,891$ & $57.4 \pm 8.6$ & $86.1 \pm 12.8$ & $1,004,753 \pm 149,734$ \\
\hline 1995 & $9,177,982$ & $59.6 \pm 8.8$ & $89.3 \pm 13.3$ & $820,046 \pm 121,828$ \\
\hline 1996 & $8,613,533$ & $60.9 \pm 9.0$ & $91.4 \pm 13.6$ & $787,041 \pm 116,784$ \\
\hline 1997 & $7,702,975$ & $60.4 \pm 8.9$ & $90.5 \pm 13.4$ & $697,499 \pm 103,265$ \\
\hline 1998 & $6,603,425$ & $61.3 \pm 9.1$ & $91.9 \pm 13.6$ & $607,072 \pm 89,821$ \\
\hline 1999 & $6,027,635$ & $59.2 \pm 8.8$ & $88.8 \pm 13.1$ & $535,101 \pm 79,246$ \\
\hline 2000 & $4,911,254$ & $52.7 \pm 7.6$ & $79.1 \pm 11.4$ & $388,377 \pm 55,951$ \\
\hline
\end{tabular}
emission flux $\left(\mathrm{Q}_{\mathrm{em}}\right)$ is shown in Table 2. $\mathrm{Q}_{\mathrm{ox}}$ is the difference between the $\mathrm{CH}_{4}$ emission flux $\left(Q_{e m}\right)$ and $\mathrm{CH}_{4}$ influx. The $\mathrm{CH}_{4}$ influx was calculated using Eq. (12). The values of OX and R were estimated using Eq.

Table 1. Results of DOC Values for the Annually Disposed Wastes at SLS 1 
Table 2. Summary of the $\mathrm{CH}_{4}$ Flow Balance (Unit: $\mathrm{m}^{3}-\mathrm{CH}_{4} \min ^{-1}$ )

\begin{tabular}{|c|c|c|c|c|c|c|}
\hline Year & $\mathbf{Q}_{\mathrm{g}}$ & $\mathbf{Q}_{\mathrm{c}}$ & $\mathbf{Q}_{\mathrm{em}}$ & $\mathbf{Q}_{\mathrm{ox}}$ & OX (\%) & R (\%) \\
\hline 2005 & 124.76 & 112.87 & 0.14 & 11.75 & 98.82 & 90.47 \\
\hline 2006 & 108.21 & 98.96 & 0.22 & 9.03 & 97.62 & 91.45 \\
\hline 2007 & 90.35 & 80.07 & 2.82 & 7.46 & 72.57 & 88.62 \\
\hline 2008 & 70.29 & 59.44 & 2.78 & 8.07 & 74.38 & 84.56 \\
\hline 2009 & 56.61 & 51.49 & 0.12 & 5.00 & 97.65 & 90.96 \\
\hline 2010 & 55.68 & 47.05 & 0.21 & 8.42 & 97.57 & 84.49 \\
\hline 2011 & 44.55 & 37.72 & 0.86 & 5.97 & 87.40 & 84.67 \\
\hline 2012 & 45.51 & 35.98 & 0.01 & 9.52 & 99.90 & 79.06 \\
\hline 2013 & 46.01 & 31.11 & 0.29 & 14.61 & 98.05 & 67.61 \\
\hline 2014 & 37.55 & 29.18 & 0.23 & 8.08 & 96.54 & 77.70 \\
\hline
\end{tabular}

(13) and (14). Table 2 shows the $\mathrm{CH}_{4}$ flow balance results for SLS 1, which reveal that $67-91 \%$ of the generated gas was collected. The results generally agree with the efficiencies reported in the literature, whereby a landfill installed with a final clay cover and active LFG extraction system can achieve LFG recovery efficiencies of up to $85 \%$ [3]. SLS 1 had a combination of final cover soils and active gas collection systems.

However, the estimated annual $R$ values at SLS 1 decreased by about $17 \%$ from $84.67 \%$ in 2011 to $67.61 \%$ in 2013 , due to the broken LFG collection piping and moisture condensation. Differential settlement can lead to breakage of the LFG collection piping. Moreover, the LFG is saturated with water vapor; when LFG cools in the LFG collection piping, moisture condensation is produced in the piping, thus clogging the piping.

Table 2 shows that OX ranged from 72.57 to $99.90 \%$. $\mathrm{CH}_{4}$ emission flux $\left(Q_{e m}\right)$ showed a significant increase with decreasing OX values in the period between 2007 and 2008. This may be because the final cover systems were subjected to differential settlement and closed LFG flare systems, which were areas with lower flow resistance, causing lateral gas transport, resulting in a much higher $\mathrm{CH}_{4}$ emission flux.

$\mathrm{CH}_{4}$ oxidation in landfill cover soils can range from negligible to $100 \%$ in field settings. According to Park et al. [18], OX values in a landfill range from 46 to $64 \%$. Börjesson et al. [19] showed that $O X$ values for closed landfill sites range from 30.8 to $46.9 \%$. The higher $O X$ values obtained in this study can be explained by the soil texture and layer thickness in addition to the low $\mathrm{CH}_{4}$ influx under the cover soil. A thicker layer can also allow a higher $\mathrm{CH}_{4}$ oxidation rate, because the temperature and moisture might be more suitable and remain more stable than in a thin cover, since the thicker layer is less subject to drying from wind and solar radiation $[8,20]$. In addition, the landfill surfaces in this study were covered with final soil covers that included a $0.6 \mathrm{~m}$ vegetation cover, which provides a sufficient supply of oxygen. According to Abichou et al. [21], plant roots can enhance the aeration of soil by creating secondary macropores.

Another reason for the increase in $\mathrm{CH}_{4}$ oxidation is the high LFG gas recovery, resulting in decreasing $\mathrm{CH}_{4}$ influx in a landfill cover soil. When $\mathrm{CH}_{4}$ influxes are high in a landfill, using a gas collection system can reduce the $\mathrm{CH}_{4}$ influx, resulting in improved
$\mathrm{CH}_{4}$ oxidation efficiency [22]. According to Abichou et al. [21] and Rachor et al. [23], OX can be highest (> 90\%) for $\mathrm{CH}_{4}$ influx less than $10 \mathrm{~g} \mathrm{~m}^{-2} \mathrm{~d}^{-1}\left(\mathrm{~g} / \mathrm{m}^{2} \mathrm{~d}\right.$ ). Geck et al. [24] showed that oxidation

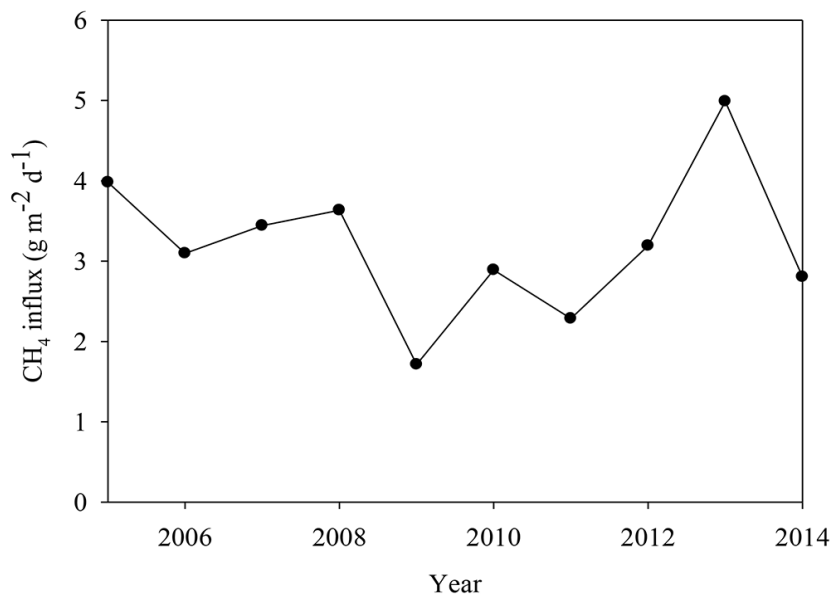

Fig. 1. Change in $\mathrm{CH}_{4}$ influx with time.

of $17.1 \mathrm{~g} \mathrm{~m}^{-2} \mathrm{~d}^{-1}$ in conventional landfill covers seems realistic. Fig. 1 shows that $\mathrm{CH}_{4}$ influxes for SLS1 were less than $5 \mathrm{~g} \mathrm{~m}^{-2}$ $\mathrm{d}^{-1}$, causing high OX ranges of $72.57 \%$ to $99.90 \%$. Besides, $\mathrm{CO}_{2}$ production through high $\mathrm{CH}_{4}$ oxidation appears to make a significant contribution to high $\mathrm{CO}_{2}$ surface emission flux.

According to Amini et al. [7], assuming that the OX ranges from 5 to $20 \%$, uncertainty is insignificant when estimating $\mathrm{CH}_{4}$ emissions using the FOD model. However, the OX values obtained from this study and previous literature [18] in Korean landfills were higher than those of the criteria prescribed by Amini et al. [7]. Thus, in order to reduce the uncertainty of the $\mathrm{CH}_{4}$ emission estimation when FOD models are applied to Korean landfills, site-specific OX values need to be estimated.

\subsection{Estimation of $\mathrm{k}$ and $\mathrm{DOC}_{\mathrm{f}}$ Using Carbon Flow Balance}

Table 3 shows the results of carbon flow balance. The total quantity of carbon $\left(\mathrm{C}_{\mathrm{s}}\right)$ generated via $\mathrm{LFG}$ and leachate was calculated using Eq. (6)-(8). The quantity of carbon generated in $\mathrm{LFG}\left(\mathrm{C}_{\mathrm{g}}\right)$ and leachate $\left(\mathrm{C}_{\mathrm{le}}\right)$ was estimated using Eq. (4) and (5). The total annual amounts 
Table 3. Summary of Carbon Flow Balance (Unit: Mg y-1)

\begin{tabular}{|c|c|c|c|c|c|c|}
\hline Year & $\mathrm{C}_{\mathrm{s}}$ & $\mathrm{C}_{\mathrm{g}}$ & $\mathrm{C}_{\mathrm{c}}$ & $\mathrm{C}_{\text {in }}$ & $\mathrm{C}_{\mathrm{le}}$ & $\mathrm{C}_{\mathrm{le}} / \mathrm{C}_{\mathrm{s}} \times 100$ \\
\hline 2005 & 59,887 & 59,581 & 53,884 & 5,696 & 307 & 0.51 \\
\hline 2006 & 51,639 & 51,370 & 46,966 & 4,404 & 269 & 0.52 \\
\hline 2007 & 42,939 & 42,706 & 37,835 & 4,871 & 233 & 0.54 \\
\hline 2008 & 34,578 & 34,340 & 29,038 & 5,302 & 238 & 0.69 \\
\hline 2009 & 27,837 & 27,602 & 25,108 & 2,495 & 234 & 0.84 \\
\hline 2010 & 27,400 & 27,113 & 22,909 & 4,204 & 288 & 1.05 \\
\hline 2011 & 22,220 & 21,937 & 18,575 & 3,362 & 283 & 1.27 \\
\hline 2012 & 22,230 & 22,008 & 17,398 & 4,609 & 222 & 0.99 \\
\hline 2013 & 22,416 & 22,255 & 15,047 & 7,208 & 160 & 0.71 \\
\hline 2014 & 18,283 & 18,170 & 14,118 & 4,052 & 113 & 0.62 \\
\hline
\end{tabular}

of DOC $\left(\mathrm{C}_{\mathrm{s}}\right)$ in 2014 were significantly lower than those in 2005. The proportions of DOC emitted via LFG were about $99 \%$ of the total carbon emissions, while those of DOC emitted via leachate ranged from 0.51 to $1.27 \%$. Generally, the amounts of DOC lost with the leachate are less than 1\% [1]. Previous studies reported that less than $2 \%$ of the total input carbon is emitted through leachate in landfills [9, 25]. The low proportion of DOC emitted through leachate can be explained by the low hydraulic conductivities of compacted municipal solid waste (MSW), which impedes water flow. Jang et al. [26] reported that the hydraulic conductivities of waste at the Sudokwon landfill ranges from 2.91 $\times 10^{-4}$ to $2.95 \times 10^{-3} \mathrm{~cm} \mathrm{~s}^{-1}$. Leachate migration through compacted MSW is relatively slow, resulting in sufficient residence time and environmental conditions for carbon degradation in the landfill.

Fig. 2 shows the relationship between rainfall and the leachate generation rate. As expected, the leachate production rate for SLS 1 ranged from 289,810 to $811,760 \mathrm{~m}^{3} \mathrm{y}^{-1}$, depending largely on the rainfall. However, the amount of DOC emitted in leachate tended to decrease with time, despite the fluctuating rainfall. When the total annual rainfall was in excess of $1,500 \mathrm{~mm} \mathrm{y}^{-1}$, the proportions of DOC emitted via leachate were $1.05 \%$ in 2010 , and $1.27 \%$ in 2011. This decreasing trend can be attributed to a reduction in the amount of DOC in the landfill during the time series.

If LFG data are available, the $k$ value can be selected by model fitting and regression using the first-order model [2]. The $k$ value was calculated by non-linear regression using Sigma-Plot software (version 10.0). Fig. 3 shows the curve-fitted line using Eq. (15) to calculate the $k$ value. Eq. (20) gives the result, and the correlation coefficient was 0.98 .

$$
C_{t, 2001}=120,638 e^{-0.1463 t}
$$

The $k$ value was $0.1463 \mathrm{y}^{-1}$. A $k$ value of $0.1463 \mathrm{y}^{-1}$ indicates that the $\mathrm{CH}_{4}$ generation rate in the studied landfill was higher than the default $k$ prescribed by the IPCC [1], which is $0.09 \mathrm{y}^{-1}$ in boreal and temperate climates. A major cause for such a $k$ value is probably the high proportion of food waste disposed in the studied landfill, as reported in Table S1. Food waste typically contains high moisture content, resulting in an accelerated rate of decomposition for other wastes.

However, the $k$ value may be affected by the internal landfill conditions (e.g. temperature, moisture), weather conditions and cover layer. In addition, each waste component degrades at a different rate, which implies that declining proportions of rapidly degrading

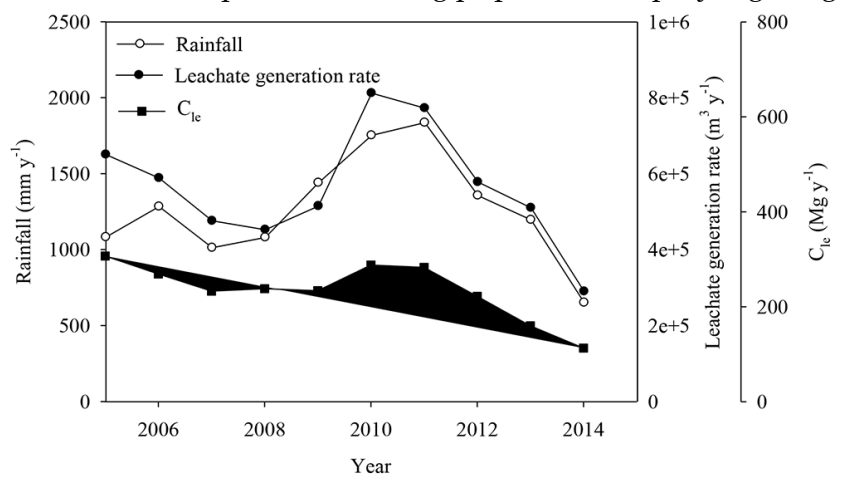

Fig. 2. Change in rainfall, leachate generation rate, and amount of DOC emitted via leachate $\left(C_{\mathrm{le}}\right)$ with time.

waste fractions may lead to changing $k$ values over time. This indicates the difficulty in estimating a constant $k$ value for aggregate waste with changing waste properties [27]. According to Govindan and Aqamuthu [28], the aggregate waste approach has higher error estimates, compared with the waste composition approach. Therefore, further studies are required to evaluate the waste component-specific decay rates using the waste composition approach.

The carbon emissions were modelled using LandGEM (Eq. (16)), with $L_{0}$ values between 10 and $30 \mathrm{~m}^{3} \mathrm{Mg}^{-1}$. Fig. 4 shows that the best fitted $L_{0}$ value proved to be $20 \mathrm{~m}^{3} \mathrm{Mg}^{-1}$, which resulted in model results that corresponded to the measured data.

In addition, error function analysis was used to conduct the $L_{0}$ validation. Error function analysis is a significant statistical analysis used to prove the accuracy of the model prediction [28]. In this study, the normalized mean square error (NRMSE) was used to validate the $L_{0}$ value using Eq. (21):

$$
N R M S E=\sqrt{\frac{(C m-C a)^{2}}{C m C a}}
$$

where, $\mathrm{Cm}$ and $\mathrm{Ca}$ are the measured $\mathrm{CH}_{4}$ and calculated $\mathrm{CH}_{4}$, respectively. 
Table 4. Comparison of $L_{0}$ and $k$ values Obtained in the Previous Literature

\begin{tabular}{|c|c|c|c|c|}
\hline Landfill & $\mathrm{L}_{0}\left(\mathrm{~m}^{3}-\mathrm{CH}_{4} \mathrm{Mg}^{-1}\right)$ & $k\left(y^{-1}\right)$ & Country & References \\
\hline Five landfills & $56-77$ & 0.04-0.13 & Florida, USA & [2] \\
\hline Two cells in a landfill & $48.4(34.7-58.2)$ & $0.06-0.11$ & Louisville, USA & [6] \\
\hline One landfill & $13-30$ & $0.07-0.36$ & Italy & [29] \\
\hline One landfill & - & 0.08-0.09 & Malaysia & {$[28]$} \\
\hline One landfill & 120 & 0.18 & Finnish & {$[27]$} \\
\hline SLS 1 & $33.7-46.7$ & 0.24 & Korea & This study \\
\hline
\end{tabular}

Table S4 gives the error estimates from NRMSE. The best fitting value of $L_{0}$ from the error function analysis was $20 \mathrm{~m}^{3} \mathrm{Mg}^{-1}$. Fig. 4 shows that the peak carbon emissions rate derived from the

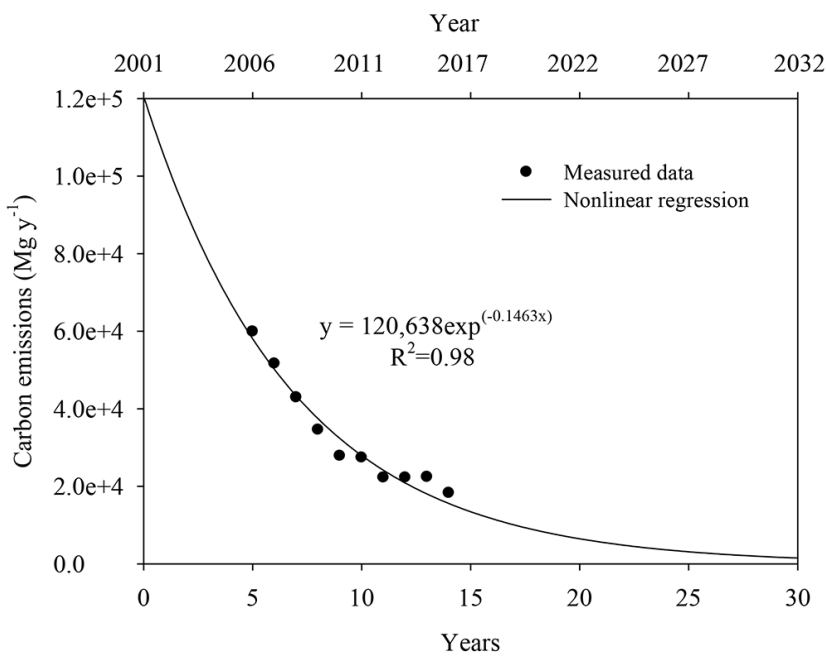

Fig. 3. Curve fitting for the annual carbon emissions at SLS 1.

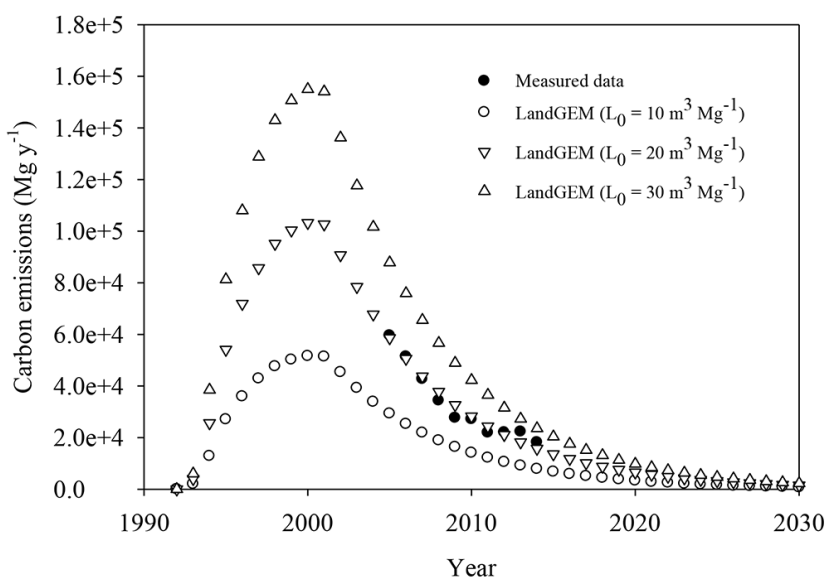

Fig. 4. Annual carbon emissions by varying $L_{0}$ compared with actual carbon emissions.

LandGEM was estimated to be $103,193 \mathrm{Mg} \mathrm{y}^{-1}$. The peak carbon emissions rate derived from the LandGEM is more than that obtained from Eq. (20). One possible explanation is that annual carbon emissions estimated through the LandGEM are calculated at the end of each year, while those obtained from Eq. (20) are plotted to the first of the year.

Table 4 shows the $k$ value obtained from this study was generally within the ranges reported in the literature. However, the $L_{0}$ value obtained from SLS 1 was lower than those reported in the literature. One possible explanation is that the carbon emissions from food waste is not considered in the selection of $L_{0}$, resulting in a smaller $L_{0}$ value.

IPCC [1] reported that the half-life values for food waste occur in the range 3-6 y in boreal and temperate climates, which indicate that food waste produces more $\mathrm{CH}_{4}$ because it decomposes promptly compared with other wastes. Thus, food waste is unable to continuously yield more $\mathrm{CH}_{4}$ after closure of a landfill. However, we only have recorded the gas data for the years 2005 to 2014 and have extrapolated this to obtain the data for the years 1992-2004; this could lead to an error in the estimate. Thus, more LFG data from during the landfill operation period are needed to improve the accuracy of the FOD LFG model parameters.

To more accurately model carbon emissions, $L_{0}$ and $k$ values were applied to two waste streams: (1) food waste, and (2) non-food wastes. It was assumed that food waste did not influence the estimated $L_{0}$ of $20 \mathrm{~m}^{3} \mathrm{Mg}^{-1}$ and $k$ of $0.1463 \mathrm{y}^{-1}$. Thus, the $L_{0}$ and $k$ values for non-food wastes were set at $20 \mathrm{~m}^{3} \mathrm{Mg}^{-1}$ and 0.1463 $\mathrm{y}^{-1}$, respectively. The $L_{0}$ for the food waste was calculated using the ultimate $\mathrm{CH}_{4}$ yield $\left(117.1 \mathrm{~m}^{3} \mathrm{Mg}^{-1}\right.$, see Table 1) and $D O C_{f}$ derived from laboratory measurement. The $D O C_{f}$ value for food waste suggested by Eleazar et al. [30] is 0.84. Using these values, the $L_{0}$ was estimated as $98.4 \mathrm{~m}^{3} \mathrm{Mg}^{-1}$ for the food waste $\left(L_{0}=\right.$ $\left.117.1 \mathrm{~m}^{3} \mathrm{Mg}^{-1} \times 0.84=98.4 \mathrm{~m}^{3} \mathrm{Mg}^{-1}\right)$.

In this study, the $k$ value for the food waste was determined through comparison of the modeled versus measured results. The selected parameter $k$ minimized the NRMSE for measured and modeled data, which were the sum of the carbon emissions for both food waste and non-food wastes. The best-fitting value of $k$ from the error function analysis using Eq. (21) was $0.45 \mathrm{y}^{-1}$, as shown in Table S5. Fig. S1 provides a comparison of measured and modeled annual carbon emissions using two waste streams. The total carbon emissions were the sum of the modeled carbon emissions for both food waste and non-food wastes. The results show that the modeled carbon emissions for non-food wastes were similar to the measured data, which implies that the food waste did not generate significant annual carbon emissions for the years 2005 to 2014.

The carbon emissions from 1992 to 2030 were calculated using LandGEM based on the estimated $L_{0}$ and $k$ values for both food waste and non-food wastes. The results show that the total amount 
of carbon emissions via LFG and leachate was $2,358,663 \mathrm{Mg}$. Considering that the total disposed $D O C$ was $5,869,626 \mathrm{Mg}$, the $D O C_{f}$ was 0.40 , which implies that $40 \%$ of $D O C$ was decomposed and the remaining $60 \%$ was stored within the landfill.

In this study, a single $k$ value for SLS 1 was calculated using the composition of the disposed waste (see Table S1). The results show $k$ values for food waste and non-food wastes as 0.45 and $0.1463 \mathrm{y}^{-1}$, respectively. Thus, the $k$ value $\left(k_{\text {total }}\right)$ of the landfilled waste could be calculated from a weighted average (wt.fraction) of the $k$ values for food waste and non-food wastes, as described in Eq. (22):

$$
\begin{aligned}
& k_{\text {total }}=\left(k_{\text {food }} \times \text { wt.fraction } \text { food }_{\text {frod }}\right) \\
& +\left(k_{\text {noon-food }} \times w t \text {. fraction }{ }_{\text {non-food }}\right)
\end{aligned}
$$

Using Eq. (22), the $k$ value was calculated as $0.24 \mathrm{y}^{-1}$ for the SLS 1. The first-order carbon emission model was used to validate the $D O C_{f}$ and $k$ values derived from this study. Fig S2 provides a comparison of the modeled nonlinear regression using Eq. (19), the modeled carbon emission using the $D O C_{f}$ value of 0.40 and $\mathrm{k}$ value of $0.24 \mathrm{y}^{-1}$, and the measured carbon emission data for SLS 1. It can be seen that the models closely fit the actual data, which implies that carbon flow balance methods are appropriate for use in estimating the $k$ and $D O C_{f}$ values and for predicting the long-term carbon emissions from landfills.

The $D O C_{f}$ value of 0.40 is within the reported range for landfills. For a conventional landfill, $17 \%$ of the entering organic carbon is emitted through gaseous emissions, which means that $D O C_{f}$ is 0.17 [24]. De la Cruz et al. [31] estimated that $0.66 \pm 0.16 \mathrm{~g}$ of biogenic carbon is stored per $\mathrm{g}$ of biogenic carbon of waste, which implies that $D O C_{f}$ ranges $0.18-0.50$ (average 0.34).

DOC that does not degrade is considered to be stored within the landfill [32]. According to Christensen et al. [33], carbon storage is one of the significant factors in greenhouse gas life-cycle analysis for landfills. In this study, the carbon storage factor for SLS 1 was $0.055 \mathrm{~g}-\mathrm{DOC}$ stored per g-wet waste. Assuming that the moisture content of the wastes was $30 \%$, the carbon storage factor was 0.039 g-DOC stored per g-dry waste. De la Cruz et al. [31] showed that carbon storage factors range from 0.01 to 0.2 g-DOC stored per g-dry waste.

The $L_{0}$ values reported in Table 1 were corrected by multiplying by $D O C_{f}$. As discussed above, the $D O C_{f}$ needs to be applied to $L_{0}$ because of the use of the ultimate $\mathrm{CH}_{4}$ yield values measured in the BMP test. Table $\mathrm{S} 6$ shows the resulting corrected $\mathrm{L}_{0}$ values

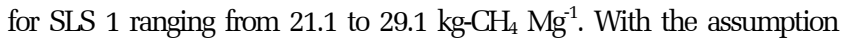
of a constant $\mathrm{CH}_{4}$ density $\left(0.716 \mathrm{~kg} \mathrm{~m}^{-3}\right.$ at $\left.0^{\circ} \mathrm{C}\right)$, the $L_{0}$ values could be expressed volumetrically, and thus ranged from 33.7 to 46.7 $\mathrm{m}^{3}-\mathrm{CH}_{4} \mathrm{Mg}^{-1}$.

\section{Conclusions}

In order to improve the accuracy of the FOD model, the parameters ( $L_{0}$ and $k$ ) in the FOD model should be determined under site-specific landfill conditions. However, when $L_{0}$ and $k$ values are determined using the LFG extraction data, the errors in the estimated $L_{0}$ based on assumptions for DOC and $\mathrm{DOC}_{\mathrm{f}}$ can affect the estimates of $k$ [6]. Thus, in order to improve accuracy of $L_{0}$ and $k$ values, the determination of the $\mathrm{DOC}$ and $\mathrm{DOC}_{\mathrm{f}}$ are important.

This study provides a methodology based on extensive data that can be used to estimate the FOD LFG model parameters. DOC can be estimated using a BMP test based on an assumed $\mathrm{DOC}_{\mathrm{f}}$ value of 1.0, because the BMP value generally represents an upper limit on the $\mathrm{CH}_{4}$ potential of MSW. The results of the study show that $\mathrm{CH}_{4}$ and carbon flow balance methods can be used appropriately to estimate model parameters and predict the long-term carbon emissions from landfills. Thus, FOD models can be used to better estimate $\mathrm{CH}_{4}$ generation and emissions if site-specific input data are used. The carbon storage factor for SCL 1 was 0.055 g-DOC stored per g-wet waste and the amounts of DOC lost with the leachate were less than $1.3 \%$. The appropriate $k$ for bulk waste was $0.24 \mathrm{y}^{-1}$. The $L_{0}$ values ranged $33.7-46.7 \mathrm{~m}^{3}-\mathrm{CH}_{4} \mathrm{Mg}^{-1}$, based on the $D O C_{f}$ value of 0.40 .

However, this study revealed a limitation about the $\mathrm{CH}_{4}$ and carbon flow balance methods. The $L_{0}$ and $k$ values were calculated using field data, but the food waste was not considered in the selection of these two key parameter values. This was because food waste has a short half-life value and thus is unable to continuously yield more $\mathrm{CH}_{4}$ after closure of a landfill. The scarcity of gas data during the period of landfill operation might mislead estimation of FOD model parameters. It should be noted that if the gas data generated after closure of a landfill is used to perform regression analysis, different $L_{0}$ and $k$ values can be reached. Nevertheless, the $\mathrm{CH}_{4}$ and carbon flow balance methods used here to estimate the FOD model parameters are recommended as the optimum method if long-term LFG data are available.

\section{Acknowledgments}

This work was supported by a National Research Foundation of Korea (NRF) grant (No. 2016R1A2B4011548), funded by the Korea government (MSIP).

\section{Nomenclature}

$\mathrm{C}_{\mathrm{g}, \mathrm{t}} \quad$ amount of carbon generated via LFG at $\mathrm{t}$ year, $\mathrm{Mg} \mathrm{y}^{-1}$

$\mathrm{C}_{\mathrm{le}, \mathrm{t}}$ the amount of carbon emitted via leachate at $\mathrm{t}$ year, $\mathrm{Mg}^{-1}$

$\mathrm{C}_{\mathrm{c}} \quad$ amount of carbon collected through the LFG collection system, Mg $\mathrm{y}^{-1}$

$\mathrm{C}_{\mathrm{em}} \quad$ amount of carbon emitted via LFG, Mg $\mathrm{y}^{-1}$

$\mathrm{C}_{\text {in }} \quad$ amount of carbon in LFG flux under the landfill cover soil, $\mathrm{Mg} \mathrm{\textrm {y } ^ { - 1 }}$

$\mathrm{C}_{\mathrm{ox}} \quad$ amount of carbon oxidized through the cover soil, $\mathrm{Mg}^{-1}$

$\mathrm{C}_{\mathrm{t}} \quad$ amount of carbon emissions at year $\mathrm{t}$

$\mathrm{CH}_{4}$ influx $\mathrm{CH}_{4}$ flux under the landfill cover soil, $\mathrm{m}^{3} \mathrm{y}^{-1}$

$\mathrm{CO}_{2}$ influx $\mathrm{CO}_{2}$ flux under the landfill cover soil, $\mathrm{m}^{3} \mathrm{y}^{-1}$

$\mathrm{COD}_{\text {con,t }}$ COD concentration of leachate at $\mathrm{t}$ year, $\mathrm{mg} \mathrm{L}^{-1}$

DOC degradable organic carbon in waste, $\mathrm{kg} \mathrm{Mg}^{-1}$

$\mathrm{DOC}_{\mathrm{f}}$ fraction of DOC that can decompose 
$\mathrm{DDOC}_{\mathrm{m}}$ mass of decomposable DOC

$\mathrm{F} \quad$ volume fraction of $\mathrm{CH}_{4}$ in the landfill gas

$\mathrm{k} \quad \mathrm{CH}_{4}$ generation rate constant, $\mathrm{y}^{-1}$

$\mathrm{L}_{0} \quad \mathrm{CH}_{4}$ generation potential $\left(\mathrm{m}^{3}-\mathrm{CH}_{4} \mathrm{Mg}^{-1}\right)$

MCF $\quad \mathrm{CH}_{4}$ correction factor for aerobic decomposition

OX oxidation factor, \%

Qc collected $\mathrm{CH}_{4}, \mathrm{~m}^{3} \mathrm{y}^{-1}$

Qem emitted $\mathrm{CH}_{4}, \mathrm{~m}^{3} \mathrm{y}^{-1}$

Qg generated $\mathrm{CH}_{4}, \mathrm{~m}^{3} \mathrm{y}^{-1}$

Qox ${ }_{\mathrm{t}} \quad$ oxidized $\mathrm{CH}_{4}, \mathrm{~m}^{3} \mathrm{yr}^{-1}$

$\mathrm{R} \quad \mathrm{CH}_{4}$ recovery efficiency, \%

$\Delta \mathrm{S} \quad$ change in $\mathrm{CH}_{4}$ storage, $\mathrm{m}^{3} \mathrm{y}^{-1}$

$V_{\text {LFG,t }} \quad$ volume fraction of LFG at $t$ year, $m^{3} y^{-1}$

$\mathrm{W}_{\mathrm{t}} \quad$ mass of waste deposited at time $\mathrm{t}, \mathrm{Mg} \mathrm{\textrm {y } ^ { - 1 }}$

\section{References}

1. IPCC. IPCC guidelines for national greenhouse gas inventories: Intergovernmental panel on climate change. Vol. 5. Waste, IGES, Japan; 2006.

2. Amini HR, Reinhart DR, Mackie KR. Determination of first-order landfill gas modelling parameters and uncertainties. Waste Manage. 2012;32:305-316.

3. Spokas K, Bogner J, Chanton JP, et al. Methane mass balance at three landfill sites: What is the efficiency of capture by gas collection systems. Waste Manage. 2006;26:516-525.

4. Laner D, Fellner J, Brunner PH. Site-specific criteria for the completion of landfill aftercare. Waste Manage. Res. 2012;30:88-99.

5. Cho HS, Moon HS, Kim JY. Effect of quantity and composition of waste on the prediction of annual methane potential from landfills. Bioresour. Technol. 2012;109:86-92.

6. Tolaymat TM, Green RB, Hater GR, et al. Evaluation of landfill gas decay constant for municipal solid waste landfills operated as bioreactors. J. Air Waste Manage. Assoc. 2010;60:91-97.

7. Amini HR, Reinhart DR, Niskanen A. Comparison of first-order-decay modeled and actual field measured municipal solid waste landfill methane data. Waste Manage. 2013;33:2720-2728.

8. Scheutz C, Kjeldsen P, Bogner JE, et al. Microbial methane oxidation processes and technologies for mitigation of landfill gas emissions. Waste Manage. Res. 2009;27:409-455.

9. Kim HJ, Matsuto T, Tojo Y. An investigation of carbon release rate via leachate from an industrial solid waste landfill. Waste Manage. Res. 2011;29:612-621.

10. He PJ, Qu X, Shao LM, Li GJ, Lee DJ. Leachate pretreatment for enhancing organic matter conversion in landfill bioreactor. J. Hazard. Mater. 2007;142:288-296.

11. SUDOKWON landfill site management corporation. An analysis of the generation and characteristics of landfill gas from Sudokwon landfill. SLC; 2015.

12. SUDOKWON landfill site management corporation. Sudokwon landfill statistics yearbook. SLC; 2015.

13. Jeon EJ, Bae SJ, Lee DH, et al. (2007) Methane generation potential and biodegradability of MSW components. In: Eleventh Int. Waste Manage. Landfill Symposium; 1-5 October 2007; Sardinia, Italy. Margherita di Pula: CISA; 2007.

14. Christophersen M, Kjeldsen P, Holst H, Chanton J. Lateral gas transport in soil adjacent to an old landfill: Factors governing emissions and methane oxidation. Waste Manage. Res. 2001;19:126-143.

15. Garg A, Achari G, Joshi RC. A model to estimate the methane generation rate constant in sanitary landfills using fuzzy synthetic evaluation. Waste Manage. Res. 2006;24:363-375.

16. US EPA. Landfill Gas Emissions Model (LandGEM) Version 3.02 User's Guide; Washington, DC: US Environmental Protection Agency; 2005.

17. Mou Z, Scheutz C, Kjeldsen P. Evaluating the biochemical methane potential (BMP) of low-organic waste at Danish landfills. Waste Manage. 2014;34:2251-2259.

18. Park J-K, Lee W-J, Ban J-K, Kim E-C, Lee N-H. Estimation of $\mathrm{CH}_{4}$ oxidation efficiency in an interim landfill cover soil using $\mathrm{CO}_{2} / \mathrm{CH}_{4}$ ratios. Environ. Eng. Res. 2015;20:191-197.

19. Börjesson G, Samuelsson J, Chanton J. Methane oxidation in Swedish landfills quantified with the stable carbon isotope technique in combination with an optical method for emitted methane. Environ. Sci. Technol. 2007;41:6684-6690.

20. Einola J, Sormunen KM, Rint ala JA. Methane oxidation in a boreal climate in an experimental landfill cover composed from mechanically-biologically treated waste. Sci. Total Environ. 2008;407:67-83

21. Abichou T, Kormi T, Yuan L, Johnson T, Francisco E. Modeling the effects of vegetation on methane oxidation and emissions through soil landfill final covers across different climates. Waste Manage. 2015;36:230-240.

22. Chanton JP, Powelson DK, Green RB. Methane oxidation in landfill cover soils: Is a $10 \%$ default value reasonable? J. Environ. Qual. 2009;38:654-663.

23. Rachor I, Gebert J, Gröngröft A, Pfeiffer EM. Assessment of the methane oxidation capacity of compacted soils intended for use as landfill cover materials. Waste Manage. 2011;31:833-842.

24. Geck C, Scharff H, Pfeiffer E-M, Gebert J. Validation of a simple model to predict the performance of methane oxidation systems, using field data from a large scale biocover test field. Waste Manage.2016;56:280-289.

25. Lornage R, Redon E, Lagier T. Mass balance of three municipal solid waste landfilling schemes. In: Eleventh International Waste Management and Landfill Symposium; 1-5 October 2007; Sardinia, Italy. Margherita di Pula: CISA; 2007.

26. Jang Y-S, Kim Y-W, Lee S-I. Hydraulic properties and leachate level analysis of Kimpo metropolitan landfill, Korea. Waste Manage. 2002;22:261-267.

27. Sormunen K, Laurila T, Rintala J. Determination of waste decay rate for a large Finnish landfill by calibrating methane generation models on the basis of methane recovery and emissions. Waste Manage. Res. 2013;31:975-985.

28. Govindan SS, Agamuthu P. Quantification of landfill methane using modified Intergovernmental Panel on Climate Change's waste model and error function analysis. Waste Manage. Res. 2014;32:1005-1014.

29. Corti A, Lombardi L, Frassinetti L. Landfill gas energy recovery: economic and environmental evaluation for a case study. In: Eleventh International Waste Management and Landfill Symposium; 1-5 October 2007, Sardinia, Italy. Margherita di Pula: CISA; 2007. 
30. Eleazer WE, Odle WS, Wang YS, Barlaz MA. Biodegradability of municipal solid waste components in laboratory-scale landfills. Environ. Sci. Technol. 1997;31:911-917.

31. De la Cruz FB, Chanton JP, Barlaz MA. Measurement of carbon storage in landfills from the biogenic carbon content of excavated waste samples. Waste Manage. 2013;33:2001-2005.
32. Krause MJ. Intergovernmental panel on climate change's landfill methane protocol: Reviewing 20 years of application. Waste Manage. Res. 2018;36:827-840.

33. Christensen TH, Simion F, Tonini D, Møller J. Global warming factors modelled for 40 generic municipal waste management scenarios. Waste Manage. Res. 2009;27:871-884. 